\title{
Is There A Long Run Relationship Between Human Resources Management And Employees' Productivity?
}

\author{
Oluwatomi Adedeji, \\ Assistant Lecturer Operation Unit \\ School Of Manegement Sciences, National Open University Of Nigeria
}

\begin{abstract}
The paper tends to ask a question, whether is there a long run relationship between human resources management and employees' productivity in Etisalat Nigeria telecommunication? However, the objective of paper is to examine the long run relationship between human resources management and employees' productivity in Etisalat Nigeria telecommunication. More so, primary and secondary data was adopted. The primary data make use of questionnaires analysis that was distributed to 80 members of staff of Etisalat Nigeria telecommunication while the data collected was coded to become a secondary data and a model was specified. Johansen Co-integration was adopted as the estimation techniques and the result shows that there is a long run relationship between human resources management and employee's productivity in Etisalat Nigeria telecommunication. The paper then recommends that the management should ensure effective human resources management planning in other to improve their productivity and acquire a large relative market share in the Nigerian telecommunication industry. Finally the paper concludes that a good efficient and effective human resources management structure should be able to improve employee's commitment and bring large organizational productivity.
\end{abstract}

Keywords: Human resources management, Organizational productivity, Employee's productivity, Johansen Co-integration test and employee's commitment.

\section{Introduction}

Human resources Management is define as planning, directing, controlling, organizing and coordinating of the procurement, development, compensation, integration, maintenance and separation of the human resources to the end that individual, organizational and societal objectives are accomplished. (Flippo, 1982). International labour organization has defined personnel management as the part of the management function which is primarily concerned with the human relationships within the organization. Ubeku (1995) posited that personnel management may be examined from two different angles. First, as a function of responsibility of every manager or supervisor who has people under from all of who are working towards the achievement of desired goals. Secondly, as a function in an organization which is performed by a particular department, called personnel department.

However, a manager is any person who through guidance, leadership, encouragement and motivation makes the men who form his team get the desired results. It follows, from this, that for a person to get others to work with him in a team effort in order to achieve his targets, he must know them intimately. Human resources management which involves the use of human resources planning and human resources planning is integral part of the overall planning of an organization development. Just as an organization budgets for the amount of capital to invest so much manpower requirement of the organization will be planned for and what should be the effect. Personnel management planning involves a mental process of setting objectives and finding the various means of achieving the objectives set. (Adebayo, 2012).

According to Adeoye (2013) assert that out of the various factors in business organization development MAN, MONEY, MACHINE and MATERIAL are important and the most unpredictable for example, money is scarce and difficult to get and you must have good men around to manage it. Material and machine to use are very important in human resources planning because without the availability of these items nothing is seems to be achieve. Machine could be use to record all the achievement generated during planning in order to attain organizational development and objectives.

Planning is also one of the aspect of having good training and development in an organization and this invariably will bring organizational productivity. In same vein, Adeyemi (2009) defined manpower planning as the estimation of how many qualified people are necessary to carry out the assigned tasks. However, Bankole (2000) defined manpower planning as the estimation of the quality and quality of employees in an organization development or a nation requires at a particular time in the future. According to Otokiti (2007), he argue on the basis of planning that issues and strategies in economic planning and commercial policies thus defined planning 
as the light of a definite predetermine objective by designing and manipulating of factors which governs the achievement of the given target so as to attain specific goals within the time limit which planner sets for himself.

In the same vein, Sulaimon (2014), said planning as understood by economists implies centralizer control of conscious and deliberate layout of the resources, with a definite period used in view all the economic aspects being definitely integrated and co-ordinated so that all implication and wasteful competition can be eliminated. Carol et al (2014) on their study on "Economics of socialism" defined planning as the process of defining its strategy, or direction, and making decisions on allocating its resources to pursue this strategy including its capital and people.

In our country today, many business organization have failed to meet up to this targeted objective with the same cases had forced some organization out of business. This paper tends to recognize the impact of Human Resources Management on employee's productivity and development towards achieving organizational objective through effective planning. However, the relevance of human resources management is an important aspect in an organization but there are a lot of problem human resources manager faces in discharging his/her duty. A lot of candidates seeking for employment are imposed on the human resources manager for employment and whereas majority of them are not qualified for the job, which has made a lot organization to collapsed. (Lamidi, 2014).

However, Olusanya et al (2012) belief that Human Resources Management occupies a very prominent and essential position in an organization. In every personnel managerial practice, the principal problem is that of individual difference source of human beings are irrational and cannot be predicted. He continue that there are problems human resources personnel face in their organization and he listed them as follows: Lack of specialization of study among labour causes routine, few trained employees are not well motivated in terms of compensation and benefits expected to serve as social welfare, good qualified employees are not employed by personnel while wrong people are sometimes employed with settlement, thereby making the recruitment and selection process meaningless. Therefore the objective of the paper is to examine the impact of human resources management on employee's productivity and this paper bring to record new innovation in methodology in addressing the relationship between human resources management and employees productivity with the use of both primary and secondary data and the estimation techniques such as unit root test, Johansen co-integration and error correction mechanism to address the topic.

\section{Literature Review And Theoretical Framework}

The impact of Human Resource Management on employee's performance helps to know various names in the past, such as human relations, labour management, personnel management, administrative managements and most recently Human Resource Management where some new scholars however are trying to introduce a new name called Human Resources Accounting (Lawal, 2014). According to Lawal, he said there are four main resources in the management namely Man, Machine, Money and materials but the essence of Human Resource Management is efficient and effective utilization of man.

However, Obanegkwe (2013) asserts that Personnel management means all efforts that are directed at acquisition and utilization of men towards accomplishment of organizational goals and maximizing the potentials of men. It is the man that source for other resources, that combine all other resources for effective use, Economic resources are believed to be scarce, but with effective human resources organizational objectives can still be accomplished, they also co-ordinate and control other resources.

He continues that the main activities of Human Resource Management are:

- Human Resources Planning : Policy formulation and organizational development

- Staffing: that is recruiting, interviewing, testing, selecting and orientating new employees, performance appraisal, promotion, transfer and separation of employees

- Training and development: that is on the job training, supervisory training, management appraisal and educational and career planning and educational programs.

- Wages and salaries administration: Non management evaluation incentive and bonus plans and executive compensation.

- Employee Services: These include tuition scholarship programmes, counseling, recreation, housing and relocation assistance, packing and eating facilities.

- Employee Benefit: These include vacation, holidays, leaves of absence, retirement benefits, saving and stock plans, profit planning programmes.

- Communication: Employees attitude surveys, in-house publication systems and community relations programmes etc.

- Work Environments: Safety programmes, health and medical services.

- Union Relations: It includes collective bargaining and arbitration. 
- Personnel Research and records keeping: Compiling facts and figures for personnel planning and compliance with government regulations.

- Discipline and control: Dealing with inexperience, incompetent, inefficient and troublesome employees.

Moreover, Falolu (2013) said the influential idea of strategic Human Resources Management "came to prominence in the 1980's in United State of America and the term "Human Resources Management 'HRM' emerged in the mid late of 1980's in Britain (Asley 2010). One way HRM is used is the simple relabeling of personnel management and industrial relations, arguable designed to capture the benefits of other meanings.

Babatunde (2011) assert that Labor economics basically look at the labor market rather than looking inside the "black box" of firms. However, industrial sociologists and psychologists started the running in Human Resource Management (HRM) but this has changed over the last two decades. Human Resource Management (HRM) can now be classified as a major field in labor economics because some economist belief that human resourcing is a labour economics phenomenon. HRM economics has a major effect on the world through teaching in business schools, and ultimately what gets practiced in many organizations.

HRM covers a wide range of activities. Incentives include remuneration systems (e.g. individuals or group incentive/contingent pay) and also the system of appraisal, promotion and career advancement. By work organization we mean the distribution of decision rights (autonomy/decentralization) between managers and workers, job design (e.g. flexibility of working, job rotation), team-working (e.g. who works with whom) and information provision. However, accoding to Bankole (2013) said space limitations means that we do not cover matching or skill development/training, and second, we will only devote a small amount of space to employee representation such as labor unions. Third, we should also mention that we focus on empirical work rather than theory and micro-econometric work rather than macro or qualitative studies. Fourth, we focus on HRM over employees rather than Chairman and Chief Executive, which is the subject of a vast literature. Where we depart from several of the existing surveys in the field is to put HRM more broadly in the context of the economics of management.

Human Resources Management (HRM) is the strategic and coherent approach to the management of an organization most valued asset that is the people working there who individually and collectively contribute to the achievements of the objective of the business (Armstrong, 2009). Different terms are used to denote Human Resources Management. They are labour management, labour administration, labour management relations, employee- employer relations, industrial relations, personnel administration, personnel management, Human Resources Management, Zabiner (2014).

Though, these terms can be differentiated widely by the basic nature of coverage and evolutionary stage. Human Resources Management means employing people, developing their resources utilizing, maintaining and compensating their services in tune with the job and organizational requirements. However, the terms Human Resources Management (HRM) and "Human resources" (HR) have largely replaced the term "personnel management" as a description of the process involved in managing people in organizations (Armstrong, 2009).

According to Adesanya (2012), Human Resources Management is both academic theory and a business practice that addresses the theoretical and practical techniques of managing a workforce. The theoretical discipline is based primarily on the assumption that employees are individuals with varying goals and needs, and as such should not be thought of as basic business resources such as trucks and filing cabinets. The fields takes a positive view of workers assuming that virtually all wish to contribute to the enterprise productively, and that the main obstacles are lack of knowledge, insufficient training and failure process.

Human Resources Management is seen by practitioners in the field as a more innovative view of workplace management than the traditional approach. Its techniques force the manager of an enterprise to express their goals with specificity so that they can be understood and undertaken by the workforce and to provide the resources needed for them to successfully accomplish their assignments. Hence when HRM techniques are properly practiced, they are expressive of the goals and operating practices of the enterprise in the overall. (Taiwo, 2010).

Nowadays, the traditional synonyms such as personnel management are often used in a more restricted sense to describe those activities that are necessary in the recruiting of a workforce, providing its members with payroll and benefits and administrating their work-life needs. (Terimoh, 2013). However, these activities can require regulatory knowledge and effort and enterprise can benefit from the recruitment and development of personnel with these specific skills.

Henry (2014), assert that the goal of Human Resources Management is to help an organization to meet its strategic goals by attracting and maintaining employees, and also to manage them effectively. The basic premise of academic theory to HRM is that humans are not machines therefore there is need to have an understanding examination of people in the workplace. 
An effective manager will want to make its employee work effectively and efficiently towards achieving the organizational goals and objectives. Thereby is fulfilling its employee objectives through compensation and benefits, Al-Mustaspha (2014).

\section{Theoretical Framwework}

In this paper, we will talk briefly on Abraham Maslows hierarchy of needs and frederick herzberg's motivation-hygiene theory.

\section{Abraham Maslow's Hierarchy Of Needs}

However, many other theorists tried to explain the importance of the human resources approach. One of these individuals was Abraham Maslow. Maslow (1943). A theory of human motivation. He is widely known for his creation of Maslow's Hierarchy of Needs. In order to get employees to work, he tried to understand what motivates people. He came up with five needs that need to be satisfied at one stage before moving on to another stage. Malsow felt that needs vary from person and person and that individual want their need fulfilled. One must determine what the motivational factor is.

Physiological Needs. The first level of Maslow's Hierarchy of Needs is psychological, which means that physical needs such as food and water need to be met before moving to the next level. If workers do not make enough money to buy food and water, then it will be hard for them to continue working.

Safety Needs. The second level is called safety. Workers need to be in a safe environment and know that their bodies and belongings will be protected. If workers don't feel secure, then they will find it hard to work efficiently. Think of the many occupations that are highly unsafe.

According to Maslow's basic theoretical premise, these individuals will have a harder time worrying about needs at the higher levels unless they can overcome the inherent lack of safety within these jobs.

Love, Affection, and Belongingness Needs. The third layer is called love, affection, and belongingness needs. Maslow believed that if an individual met the basic physiological and safety needs, then that individual would start attempting to achieve love, affection, and belongingness needs next, "He or she will hunger for affectionate relations with people in general, namely, for a place in his or her group, and he or she will strive with great intensity to achieve this goal." Maslow believed that organizations would have better worker retention and satisfaction if they kept their employees in a cohesive environment. Furthermore, if a worker feels isolated or ostracized from their environment, then he or she would feel less motivated to work, which will lead to a decrease in overall productivity.

Esteem Needs. The fourth layer is called esteem, and is represented by two different sets of needs according to Maslow. First, individuals are motivated by the "desire for strength, for achievement, for adequacy, for confidence in the face of the world, and for independence and freedom." Maslow goes on to discuss a second subset of esteem needs, "we have what we may call the desire for reputation or prestige defining it as respect or esteem from other people, recognition, attention, importance or appreciation while Maslow originally separated these two lists from each other, they clearly have more in common than not. If employees do not feel that their input is valued at the organization, they will seek out other places of employment that will value their input, because humans have an intrinsic need to be appreciated for their efforts.

Self-Actualization Needs. The fifth layer is called self-actualization, and it is the hardest to attain. Selfactualization "refers to the desire for self-fulfillment, namely, to the tendency for a person to become actualized in what he or she is potentially. This tendency might be phrased as the desire to become more and more what one is, to become everything that one is capable of becoming." Maslow goes on to explain, "A musician must make music, an artist must paint, a poet must write, if he or she is to be ultimately happy. What a man or woman can be, he or she must be. This need we may call self-actualization emphasis in original. Maslow felt that if individuals can have their needs met in order of the layers, then they would be both motivated and seek opportunities to excel.

All in all, Maslow's hierarchy of needs helps us understand how to motivate workers to strive for more in the organization. Hence, communication is very important, because we need to understand what our employees need in order to motivate them to work more proficiently and productively.

\section{Frederick Herzberg's Motivation-Hygiene Theory}

The second theory we will look at in this paper is the Frederick Herzberg's motivation Hygiene theory. He was originally trained as a clinical psychologist, over the course of Herzberg's career he switched focused and became one of the first researchers in the growing field of industrial psychology. The original notion of Frederick (1964) motivation-Hygiene Theory was that traditional perspectives on motivation, like Maslow's, only looked at one side of the coin that is how to motivate people. In Herzberg's worldview, motivation on the job should lead to satisfied workers, but he theorized that satisfaction and dissatisfaction were not opposite ends 
of one continuum. Instead, he predicted that the factors that lead to positive job attitudes and thus motivation were different from the factors that lead to negative job attitudes and thus de-motivation. For the purposes of his theory, he called the factors that led to positive job attitudes motivators and those factors that led to negative job attitudes hygiene factors. Noted that the motivators are all centered around ideas that are somewhat similar to the esteem needs and self-actualization needs of Abraham Maslow. On the other hand, the hygiene factors all examine the context of work.

Therefore, in this paper we will look at whether human resources management has improved employee's motivation which invariably may leads to positive/negative productivity in the organization.

Table 3 Result Of General Questions Distributed To The Respondents Result of General Questions Distributed to the Respondents

\begin{tabular}{|c|c|c|c|c|}
\hline Questions & $\begin{array}{l}\text { Response } \\
\text { Column }\end{array}$ & Frequency & $\begin{array}{l}\text { Cumulative } \\
\text { Frequency }\end{array}$ & Percentage (\%) \\
\hline $\begin{array}{l}\text { 1. The Human Resources } \\
\text { Management of your Company } \\
\text { (Etisalat telecommunication) has a } \\
\text { great impact on employees' } \\
\text { productivity. }\end{array}$ & $\begin{array}{l}\text { SA } \\
\text { SD } \\
\text { A } \\
\text { D }\end{array}$ & $\begin{array}{r}60.00 \\
10.00 \\
5.00 \\
5.00\end{array}$ & $\begin{array}{c}60.00 \\
70.00 \\
75.00 \\
80.00\end{array}$ & $\begin{array}{r}75.00 \\
12.50 \\
6.25 \\
6.25\end{array}$ \\
\hline $\begin{array}{l}\text { 2. Human resources planning has } \\
\text { improved your company's } \\
\text { performance in Nigeria. }\end{array}$ & $\begin{array}{l}\text { SA } \\
\text { SD } \\
\text { A } \\
\text { D }\end{array}$ & $\begin{array}{l}40.00 \\
20.00 \\
10.00 \\
10.00\end{array}$ & $\begin{array}{c}40.00 \\
60.00 \\
70.00 \\
80.00\end{array}$ & $\begin{array}{c}\mathbf{5 0 . 0 0} \\
25.00 \\
12.50 \\
12.50\end{array}$ \\
\hline $\begin{array}{l}\text { 3. If an organization is well } \\
\text { developed in its human resources } \\
\text { management areas, it will increase } \\
\text { organization growth } \\
\text { development. }\end{array}$ & $\begin{array}{l}\text { SA } \\
\text { SD } \\
\text { A } \\
\text { D }\end{array}$ & $\begin{array}{r}34.00 \\
22.00 \\
15.00 \\
9.00\end{array}$ & $\begin{array}{l}34.00 \\
56.00 \\
71.00 \\
80.00\end{array}$ & $\begin{array}{c}\mathbf{4 2 . 5 0} \\
27.50 \\
18.75 \\
11.25\end{array}$ \\
\hline $\begin{array}{l}\text { 4. Effective human resources } \\
\text { managements is one of the major } \\
\text { criteria for organizational } \\
\text { effectiveness and increased } \\
\text { profitability. }\end{array}$ & $\begin{array}{l}\text { SA } \\
\text { SD } \\
\text { A } \\
\text { D }\end{array}$ & $\begin{array}{c}67.00 \\
13.00 \\
- \\
-\end{array}$ & $\begin{array}{c}67.00 \\
80.00 \\
- \\
-\end{array}$ & $\begin{array}{c}\mathbf{8 3 . 7 5} \\
16.25 \\
- \\
-\end{array}$ \\
\hline $\begin{array}{l}\text { 5. Good Recruitment and selection } \\
\text { process brings effective human } \\
\text { resources management to the } \\
\text { organization. }\end{array}$ & $\begin{array}{l}\text { SA } \\
\text { SD } \\
\text { A } \\
\text { D }\end{array}$ & $\begin{array}{l}37.00 \\
18.00 \\
15.00 \\
10.00\end{array}$ & $\begin{array}{l}37.00 \\
55.00 \\
80.00 \\
-\end{array}$ & $\begin{array}{c}\mathbf{4 6 . 2 5} \\
22.50 \\
18.75 \\
12.50\end{array}$ \\
\hline $\begin{array}{l}\text { 6. Effective training and } \\
\text { Development in your company } \\
\text { (Etisalat telecommunication) has } \\
\text { improve } \\
\text { performance/productivity. }\end{array}$ & $\begin{array}{l}\text { SA } \\
\text { SD } \\
\text { A } \\
\text { D }\end{array}$ & $\begin{array}{c}41.00 \\
12.00 \\
17.00 \\
10.00\end{array}$ & $\begin{array}{l}41.00 \\
53.00 \\
- \\
80.00\end{array}$ & $\begin{array}{c}\mathbf{5 1 . 2 5} \\
15.00 \\
21.25 \\
12.50\end{array}$ \\
\hline $\begin{array}{l}\text { 7. Motivation is a key to employee } \\
\text { productivity in your Company } \\
\text { (Etisalat telecommunication). }\end{array}$ & $\begin{array}{l}\text { SA } \\
\text { SD } \\
\text { A } \\
\text { D }\end{array}$ & $\begin{array}{c}- \\
12.00 \\
68.00 \\
-\end{array}$ & $\begin{array}{l}- \\
12.00 \\
80.00 \\
-\end{array}$ & $\begin{array}{c}- \\
15.00 \\
85.00 \\
-\end{array}$ \\
\hline $\begin{array}{l}\text { 8. Human resources managements } \\
\text { plays a vital role in re-shaping } \\
\text { Etisalat telecommunication } \\
\text { product and services. }\end{array}$ & $\begin{array}{l}\text { SA } \\
\text { SD } \\
\text { A } \\
\text { D }\end{array}$ & $\begin{array}{c}118.00 \\
- \\
2.00 \\
-\end{array}$ & $\begin{array}{c}118.00 \\
- \\
120.00 \\
-\end{array}$ & $\begin{array}{c}98.33 \\
- \\
1.67 \\
-\end{array}$ \\
\hline $\begin{array}{l}\text { 9. Human Resources Planning have } \\
\text { a lot of impact on the branding of } \\
\text { Etisalat telecommunication. }\end{array}$ & $\begin{array}{l}\text { SA } \\
\text { SD } \\
\text { A } \\
\text { D } \\
\end{array}$ & $\begin{array}{l}5.00 \\
- \\
115.00\end{array}$ & $\begin{array}{c}5.00 \\
- \\
120.00 \\
- \\
\end{array}$ & $\begin{array}{c}4.17 \\
- \\
95.83 \\
- \\
\end{array}$ \\
\hline $\begin{array}{l}\text { 10. The Human Resources } \\
\text { management of your Company } \\
\text { (Etisalat telecommunication) has } \\
\text { improved your company rate of } \\
\text { turnover profit. }\end{array}$ & $\begin{array}{l}\text { SA } \\
\text { SD } \\
\text { A } \\
\text { D }\end{array}$ & $\begin{array}{c}104.00 \\
- \\
16.00 \\
-\end{array}$ & $\begin{array}{c}104.00 \\
- \\
120.00 \\
-\end{array}$ & $\begin{array}{c}86.67 \\
- \\
13.33 \\
-\end{array}$ \\
\hline Total & & 120 & & 100.0 \\
\hline
\end{tabular}

Source: Authors' Research Survey 2014

Where SA- Strongly Agree, SD- Strongly Disagree, A- Agree, D- Disagree. 


\section{Discussion Of Questionnaire}

Based on the questionnaire result, it is observed from the questionnaire that $75 \%$ which represent the majority of the respondents assert that the Human Resources Management of their Company (Etisalat telecommunication Nigeria) has a great impact on employee's productivity while $12.50 \%$ strongly disagree, $6.25 \%$ agree and $6.25 \%$ disagree with the statement. In addition, majority of the respondents strongly agree that Human resources planning has improved their company's performance in Nigeria. However, $42.50 \%$ of the total respondents strongly agree that if an organization is well developed in its human resources management areas, it will increase organization growth and development.

In the same vein, $83.75 \%$ of the whole respondents opine that effective human resources managements is one of the major criteria for organizational effectiveness and increased profitability. However, $46.25 \%$ of the total respondents assert that good Recruitment and selection process brings effective human resources management to the organization while $51.25 \%$ claim that effective training and Development in their company (Etisalat telecommunication) has improve employees' performance/productivity.

Moreover, $85 \%$ of the total respondents agree that motivation is a key to employee productivity in their Company (Etisalat telecommunication) while $98.33 \%$ opine that Human resources managements plays a vital role in etisalat telecommunication product and services. $95.83 \%$ of the respondents agree that Human Resources Planning have a lot of impact on the branding of etisalat telecommunication Nigeria.

In addition, all the respondents state that the Human Resources management of their Company (Etisalat telecommunication) has improved their company rate of turnover profit.

\section{Methodology}

The data used in this paper are both primary and secondary data. The primary data make use of questionnaire analysis that was distributed to Staffs of Etisalat Telecommunication Nigeria limited. However, the study population comprises 80 Staffs of Etisalat Telecommunication head office in Lagos, Nigeria. Moreover, the population has different marital status from single to married. However, the data collected through the questionnaire are coded with the use of coding system to become a group data and a model was specified to take care of the topic of the paper. However, a unit root test was conducted for stationarity of the data and Johansen co-integration was used to know whether there is long run relationship between Human Resources management and Employees' productivity in etisalat Nigeria telecommunication. Therefore, we can then specify the model for the secondary data obtained from the primary data below:

$\mathrm{HRM}=\mathrm{f}(\mathrm{EP}, \mathrm{TOP}, \mathrm{Ui})$

Where HRM = Human Resources Management of Etisalat.

$\mathrm{EP}=$ Employees Productivity.

TOP $=$ Turnover Profit of Etisalat.

However, the model can also be decomposing as follows;

$\mathrm{HRM}=\mathrm{ao}+\mathrm{a} 1 \mathrm{EP}$....

$\mathrm{HRM}=$ ao + a1TOP.

However, bringing equation 1 and 2, the model becomes;

$\mathrm{HRM}=\mathrm{a}_{0}+\mathrm{a}_{1} \mathrm{EP}+\mathrm{a}_{2}$ TOP.

Where HRM = Human Resources Management of Etisalat.

$\mathrm{EP}=$ Employees Productivity.

TOP $=$ Turnover Profit of Etisalat.

$\mathrm{Ui}=$ Error term.

\section{Unit Root Test Result}

Prior to estimation, we shall subject the data to vigorous tests in order to establish their adequacy as regards stationarity by conducting a Unit Root test

Table 1: Unit Root Test Result

\begin{tabular}{|l|l|l|}
\hline Variables & $\begin{array}{l}\text { ADF } \\
\text { T-Statistic }\end{array}$ & Order \\
\hline LNHRM & -2.544321 & $\mathbf{I}(0)$ \\
\hline LNEP & -3.655430 & $\mathbf{I}(0)$ \\
\hline LNTOP & -4.988732 & $\mathbf{I}(1)$ \\
\hline
\end{tabular}

Note: The 5\% critical value for the ADF statistic is $\mathbf{- 2 . 9 5}$

The result above in table 1 shows that human resources management of Etisalat Nigeria telecommunication (HRM), Employees Productivity (EP) are stationary at level that is they are I(0) series while turnover Profit of Etisalat (TOP) is stationary at first difference that is the variables are I(1) series. This is 
deducted from the fact that for the levels of variables, the absolute values of the ADF statistics are greater than the critical values of the $\mathrm{ADF}$ at $5 \%$ level of significance.

\subsection{Testing Of Hypothesis And Interpretation Hypothesis I}

Ho: Human resources management has no significant effect on employees' productivity.

Hi: Human resources management has a significant effect on employees' productivity.

\section{Johansen's Co-integration Test Result}

The Johanson's co-integration analysis helps to test for the existence of long run stable relationship that exists between the dependent variable and its regression. A vector of variables integrated of order one is cointegrated if there exist linear combination of variables that are stationary. Following the approach of Johansen and Juselius (1990) two likelihood ratio test statistic, the maximal eigen value and the trace statistic were utilized to determine the number of co-integration vectors.

Table 3: RESULT OF JOHANSEN Co-integration

\begin{tabular}{|l|l|l|l|l|l|}
\hline Series & Eigenvalue & $\begin{array}{l}\text { Trace } \\
\text { Value }\end{array}$ & $\begin{array}{l}\text { Percent } \\
\text { Critical value }\end{array}$ & $\begin{array}{l}\text { 1 percent } \\
\text { critical Value }\end{array}$ & $\begin{array}{l}\text { Hypothesized } \\
\text { No. of CE(S) }\end{array}$ \\
\hline LNHRM & $\mathbf{0 . 5 6 6 5 2 3}$ & $\mathbf{3 5 . 0 8 2 9 7}$ & $\mathbf{3 7 . 2 2}$ & $\mathbf{6 6 . 1 1}$ & None** \\
\hline LNEP & $\mathbf{0 . 6 5 7 6 3 2}$ & $\mathbf{3 1 . 4 4 3 2 1}$ & 31.21 & 32.35 & At most 1 \\
\hline LNTOP & $\mathbf{0 . 5 5 9 2 1 1}$ & $\mathbf{1 7 . 6 5 5 1 1}$ & $\mathbf{2 2 . 7 6}$ & $\mathbf{3 2 . 8 1}$ & At most 2 \\
\hline
\end{tabular}

*(**) denotes rejection of the null hypothesis at the $5 \%(1 \%)$ level respectively

Trace test indicates 1 co-integrating equation at both $5 \%$ and $1 \%$ level

Table above reveals that the null hypothesis of no co-integration is rejected. This implies that the long run test reveals co-integration relationship among variables that were included. The result also reveals that there is 1 Co-integration equation(s) at both $5 \%$ and $1 \%$ levels; this indicates a long run equilibrium relationship between Human Resources Management of Etisalat Nigeria telecommunication and its explanatory variables (Employees Productivity and Turnover Profit of Etisalat). We can then conclude that Human resources management of etisalat Nigeria telecommunication has a lot of influence on employees' productivity.

Table 3: Error Correlation Model

Variable: D (LNHRM)

Included Observation: 80

Excluded Observation: 2 after adjusting and points

\begin{tabular}{|l|l|l|l|l|}
\hline Variable & Co-efficient & Std. Error & T-Statistic & Prob. \\
\hline Constant & $\mathbf{0 . 0 3 4 3 2 5}$ & $\mathbf{0 . 0 6 7 2 2 3}$ & $\mathbf{1 . 8 8 7 2 3 2}$ & $\mathbf{0 . 0 0 0 0}$ \\
\hline D (LNEP(-1) & $\mathbf{0 . 0 2 3 2 2 1}$ & $\mathbf{0 . 0 2 2 3 1 1}$ & $\mathbf{0 . 5 5 4 2 2 1}$ & $\mathbf{0 . 0 0 0 2}$ \\
\hline D(LNTOP(-1) & $\mathbf{4 . 6 5 7 6 7 2}$ & $\mathbf{1 . 6 6 5 5 4 0}$ & $\mathbf{1 . 7 8 8 2 1 2}$ & $\mathbf{0 . 0 0 0 7}$ \\
\hline ECM(-1) & $\mathbf{- 2 . 8 9 8 7 2 3}$ & $\mathbf{0 . 6 5 7 6 2 2}$ & $\mathbf{4 . 6 3 5 4 2 8}$ & $\mathbf{0 . 0 0 0 1}$ \\
\hline R squared & $\mathbf{0 . 8 5 5 5 4 3}$ & Mean Dependent Var. & $\mathbf{0 . 0 5 4 8 4 3}$ \\
Adjusted R squared & $\mathbf{0 . 7 6 4 4 2 2}$ & S.D. Dependent Var. & $\mathbf{0 . 0 3 9 1 6 3}$ \\
S.E of regression & $\mathbf{0 . 6 7 7 3 3 2}$ & Akaike info Criterion & $\mathbf{6 . 3 3 2 1 1 0}$ \\
Sum squared resid. & $\mathbf{2 . 6 4 7 7 8 9}$ & Schwarz Criterion & 7.221734 \\
Log likelihood & $\mathbf{0 . 3 2 2 4 8 2}$ & F statistic & $\mathbf{5 . 5 0 0 4 6 7}$ \\
Durbin Watson stat & $\mathbf{1 . 4 3 3 4 2 1}$ & Prob (F-statistic) & $\mathbf{0 . 0 0 0 0 0 2}$ \\
\end{tabular}

Table 3 shows the error correction model and the result revealed that the lag value of employee's productivity has a positive relationship and it's statistically significantly related to Human Resources Management and is significant at $5 \%$ level of significance and shows that is contributing to the human resources management of Etisalat Nigeria telecommunication. The lagged value of turnover profit of Etisalat Nigeria telecommunication has a positive relationship with the human resources management of Etisalat Nigeria telecommunication and it significant at $5 \%$ level of significance and it also shows that is contributing to the human resources management of Etisalat Nigeria telecommunication.

\subsection{Conclusions}

The following conclusion was drawn from the result of data analysis conducted on the research work.

i. Great percentage of the respondents agreed that human resource management plays strategic role in the organizations product or service.

ii. It reveals how training and development of employee is very important in the organization. 
iii. Majority of the respondents agree that Human Resources Planning is important in acquiring a relative market share in the telecommunication industry.

iv. The sales representatives of the organization's name have been helpful in the development and growth of the company product and name.

v. It shows how effective and efficient human resources management and planning contribute to the success of the organization.

vi. According to the paprr, staffs and management of Etisalat Nigeria are aware of the benefits of human resources planning in an organisation.

vii. Efficient and effective organizational structure is also very important for the implementation of human resource planning.

viii. It was revealed from the analysis that a long run relationship exist between human resources management and employee's productivity in etisalat Nigeria telecommunication.

Therefore, human resources management should be used in the telecommunication industry to enhance patronage.

\subsection{Recommendation} industries:

We recommend the following to improve the performance of Etisalat Nigeria in the telecommunication

i. The company should put more effort on planning and organizing the department in the organization in order to increase their sales in the telecommunication industry.

ii. The management should ensure effective human resources management planning in order to aid a good branding and to acquire a large relative market share in the telecommunication industry.

iii. Effective Recruitment and selection of employee and all entire staffs of the organization.

iv. All employee of the organization should be given effective and efficient training and development activities in order to sharpen the skills and knowledge of employee of the business organization.

v. Human resources Management should be adequately used in the telecommunication industry in order to enhance availability of telecommunication products and services.

vi. The management of the company should put in place a good welfare programme for the entire staff in other for them to be more productive.

\section{References}

[1]. Adebayo, O.I. (2012). Practice of Human Resources Management, a broader perspective, $1^{\text {st }}$ edition, pg 44-57, Pat Publication limited.

[2]. Adeoye, K.D. (2013). Impact of Human Resources and Organizational Productivity, a Jourmal of Management, vol 4, pg 21-32, Mill world limited

[3]. Adeyemi O.T. (2009). Human Resource Management in Nigeria, a textbook, $2^{\text {nd }}$ edition Mushin Adeola Printers Pg. $55-60$.

[4]. Adesanya, J.K. (2012). Relationship between Human Resources and Employees Performance, a Journal of humanities, vol 7, pg 6778, Pet \& Met Publication limited.

[5]. Al-Mustapha, F. (2014). Human Resourcing and Firm performance in Nigeria, a Journal of business Management, vol 8, pg 34-46, Al-Mustaph Press limited.

[6]. Armstrong, M. T. (2009). Impact of Better Management on Firm Performance, a Journal, vol 6, pg 22-33, West point Publication limited.

[7]. Asley, M.J. (2010). The Secret of Training and Developing in a Manufacturing industry in Nigeria, Journal of development, vol 4, pg 23-47, Manaj Press limited, Lagos Nigeria.

[8]. Babatunde, H.D. (2011). Human Resources Management and Employees Productivity. Do it matter, $2^{\text {nd }}$ edition, pg 44-55, westpoint limited.

[9]. Bankole, A.R. (2013). Analysis of Human Resources and Firm Performance, a presentation on Human resources in an organization, $1^{\text {st }}$ edition Shaw Publication limited.

[10]. Bakole, D.S. (2000) Training and Development in a Government Parastatals, a broader perspective, $1^{\text {st }}$ edition, Newton Publication limited, Lagos, Nigeria.

[11]. Carol, P. \& Vancerich, Y. (2014). The Relative and Effectiveness of Training methods, expert Opinion and Research personnel Psychology, a Journal Vol 8 pg 25-35, Mcgrawhill publication.

[12]. Falolu, O.B. (2003). Research Methodology for Nigerian Tertiary Institution, $1^{\text {st }}$ edition, pg 47-59, West point Press limited.

[13]. Flippo, E.B.(1982). Principle of personnel management Networks, MC GrHill Book Company.

[14]. Henry, A. A. (2014). Can effectiveness of Human Resources leads to Organizational Performance? Journal vol 12-24, pg 79-90, BBNL Publication Company.

[15]. Herzberg, F. (1964). The Motivation-Hygiene Concept and Problems of Manpower. Personnel Administrator (27), pp. 3-7.

[16]. Jeselius, J. (1990). Analysis of Johansen Co-integration test, Jeselius Publication.

[17]. Lawal, A.A. (2014). Entrepreneurship Development in Small Scale Business in Nigeria, $2^{\text {nd }}$ edition, Dale Press limited.

[18]. Lamidi, M.F. (2014). The implication of Bad Human Resources management on organizational productivity, Journal vol 9, pg 2436, Mill world Press limited.

[19]. Maslow, H. (1943). A theory of human motivation. Psychological Review, 50(4), 370-96.

[20]. Obanegkwe, S.R. (2013). Introduction to Econometrics analysis, a wider perspective, pg 88-102, Brown Publication Company.

[21]. Olusanya, S.O \& Oyebo, A.O (2012). Training and Development, A vital Tool for Organizational effectiveness. IOSR Journal of Business and Management (IOSR-JBM) ISSN: 2278-487X. Volume XI, Issue X (Dec. 2012), www.iosrjournals.org www

[22]. Otokiti, R.F. (2007). Element of Development in a developing country, $1^{\text {st }}$ edition, Itori Press limited, Lagos, Nigeria. 
[23]. Sulaimon, A.A. (2014). Human Resources Management in Nigeria, $1^{\text {st }}$ edition, Ade-Ola Printing Press Ltd (Oshodi).

[24]. Taiwo, T.B. (2010). Managing the Radicalism of Workers in an Organization, textbook $1^{\text {st }}$ edition, pg 48-60, Saiye Printing Press limited.

[25]. Terimoh, E.D. (2013). Relationship between Human resources Management and Firm Performance, Journal vol 5, pg 12-24, UTM Publication Company.

[26]. Ubeku, A.K. (1990). Human resources Management in Public Organization, 2nd Edition Ikeja, Ola-Oluwa Printers Pg (20 -22)

[27]. Zebiner, T.E. (2014). Human Resources Management, an engine for Organizational Productivity, Journal, vol 8, pg 33-45, Dale Publication limited. 